This is an electronic version of an article published in:

Language and Education 22 (4), 298-319 (2008)

The journal is available online at:

http://www.informaworld.com/smpp/content $\sim \mathrm{db}=\mathrm{all} \sim \operatorname{content}=\mathrm{a} 907025553 \sim \mathrm{frm}=\mathrm{titlel}$ $\underline{\text { ink }}$

Intergenerational learning events around the computer: a site for linguistic and cultural exchange

Charmian Kenner, Mahera Ruby, John Jessel, Eve Gregory and Tahera Arju

Department of Educational Studies

Goldsmiths, University of London

UK

c.kenner@gold.ac.uk 


\section{Intergenerational learning events around the computer: a site for linguistic and cultural exchange}

The computer is widely recognised as a cultural tool with the potential to enhance learning, and children are considered to develop ICT skills with particular facility. However, young children still require assistance in order to gain the maximum educational benefit. This study investigates how such assistance was given to 3-6 year olds by their grandparents, in Sylheti/Bengali-speaking families and monolingual English-speaking families living in East London. A multimodal analysis of videorecorded computer activities reveals the reciprocity of teaching and learning taking place between the generations. In each case, grandparents and grandchildren combined their resources in order to negotiate the activity, with adults usually providing knowledge of literacy and numeracy whilst children helped with computer skills. The intergenerational exchange was especially evident in Sylheti/Bengalispeaking families, where grandparents were less familiar with English or with the computer and operated bilingually with their grandchildren to co-construct learning. However, the support offered by grandparents was found to have common elements in all families, as they helped children to structure the learning event, maintain concentration and accomplish tasks relying on linguistic and cultural knowledge.

Keywords: grandparents, bilingualism, Bengali, ICT, young children, multimodality

\section{Introduction}

This paper will first consider the findings of current research on how ICT can benefit young children's learning, highlighting some advantages that may be gained from adult support in computer tasks. We then introduce a research project that aimed to investigate the dynamics of intergenerational learning between children and grandparents in East London from a sociocultural perspective. The paper focuses on a particular aspect of this research, concerning interaction around the computer.

A detailed comparison is made between two video-recorded episodes, one involving a Sylheti/Bengali-speaking grandmother and her granddaughter playing a numeracy game, and the other concerning a monolingual English-speaking child and her grandmother conducting a search on the internet. The transcripts show how communication took place through gaze, touch and action as well as spoken language. This multimodal approach facilitates an in-depth examination of the learning exchange, and shows congruences as well as differences between the two episodes. Whilst the English-speaking grandparent and grandchild at first appear to be dealing with a more challenging activity, the interaction between the bilingual child and her grandmother is revealed as equally complex, involving similar categories of support for learning. In both cases, there was an interchange of knowledge and skills between the generations around literacy, language and ICT.

In conclusion, we discuss the need to increase access to ICT for grandparents and grandchildren from a wider variety of cultural backgrounds. In both bilingual and monolingual families, grandparents would then be able to provide vital support for children's learning whilst simultaneously improving their own understanding of new technologies. 


\section{The potential of ICT for early learning}

A sociocultural approach to learning holds that 'human action in the social and material world is everywhere co-ordinated through the intervention of cultural tools', and information and communication technology (ICT) now has considerable importance as a source of mediating artefacts (Crook, 2001: 21). Learning via new technology, including computers, is recognised as a key element of young children's education (Labbo and Reinking, 2003; Siraj-Blatchford, 2004), and has been reported to correlate positively with levels of attainment at school (BECTa, 2002, 2003). Guidance is being provided for educators on how to exploit ICT in the classroom (Fatouros, 1995; Haugland, 2000; Wegerif, 2002; Siraj-Blatchford and SirajBlatchford, 2005) and how parents, other caregivers, and teachers can provide a rich learning environment (Siraj-Blatchford and Whitehead, 2003).

In this relatively new research field, there is a continuing need to explore how learning interactions around ICT can best be supported for young children. As Stephen and Plowman (2002) point out, there are still more questions than answers on the kind of contribution ICT could make to early learning, including ways in which children respond to the technology. Goodison (2002) highlights the need for further research to investigate children's participation in the learning process.

In order to gain the most from learning around the computer, young children are likely to need adult guidance. An evaluation of a large-scale project in which computers were supplied to pre-school settings throughout Europe highlighted the importance of teacher support to help children learn (Siraj-Blatchford and SirajBlatchford, 2004). 'Sustained shared thinking', defined as 'sustained verbal interactions that are effectively matched to the children's interest and attention', has been identified as a key feature in enabling young children to develop ideas (ibid: 14), and an adult presence is therefore recommended to encourage questions and discussion.

Turbill's (2001) ethnographic study begins to investigate this area with children in an early years classroom. She points out that children often have an understanding of 'concepts of screen' - textual functions on the computer such as the use of hyperlinks - but would benefit from adult help with 'concepts of print' - the reading of individual words and phrases in order to navigate more successfully around software programmes. Equally important for young learners is discussion about on-screen material with an adult in order to engage more fully with the learning opportunities available. Adults can also guide interaction by structuring the activity, focusing attention, encouraging turn-taking between participating children and demonstrating manoeuvres such as clicking and dragging an item across the screen, as observed in Scottish pre-school settings (Stephen and Plowman, 2003).

Similar support can be given by caregivers at home. Giacquinta et al (1993) found children to be highly dependent on parental help when using home computers for educational purposes. This area is as yet little-researched in comparison to classroom work around ICT, particularly with regard to bilingual families.

The potential benefits of ICT for bilingual children have been discussed by Wegerif (2004), building on the finding that computer tasks can promote collaborative talk - a type of interaction particularly useful to second language learners - in classroom 
groupwork (Wegerif and Dawes, 2004). Davies (2004) points out the advantages of ICT-based materials in providing a rich context to support children's understanding and development of English as an additional language. How might caregivers at home engage in collaborative talk in computer activities with young children and exploit this valuable resource for learning?

\section{Learning with grandparents around the computer}

This paper explores the interaction between young children and their grandparents when undertaking computer activities together. The data come from a wider study of intergenerational learning between children and grandparents in East London. The project was set up to investigate how the older and younger generations contribute to each other's learning, both in activities where grandparents might be expected to take the lead (such as storytelling or cooking) and in the newer areas of ICT where children are likely to have competences their grandparents would like to access.

We focused on 3-6 year old children, since this age group particularly needs the support of caregivers, and we conducted the research with Sylheti/Bengali-speaking* families and monolingual English-speaking families, in order to examine linguistic and cultural aspects of the intergenerational exchange. With regard to language resources, we anticipated that in the British Bangladeshi families, grandparents might be providing support in Sylheti/Bengali whilst children might have more knowledge of English, and we wished to find out how they made use of these resources in order to accomplish a task bilingually. The overall findings of the study are discussed elsewhere (Jessel et al, 2004; Kenner et al, under review), but here we focus on the aspect of learning around the computer.

The study was designed and carried out within a sociocultural perspective, examining how young children and their caregivers jointly construct conceptual understandings within their particular cultural context. Sociocultural theory has built on the model originally proposed by Vygotsky (1978) of how children develop ideas through communication with others in their learning community and use internal thought processes to transfer these ideas into their individual understanding. Research in different cultural contexts (Rogoff, 1990, 2003) demonstrates the varying ways in which the interpersonal learning process can occur, and emphasises the child's active contribution through 'guided participation' with their caregiver (Rogoff, 1990: viii). Studies on children's learning at home with siblings (Rashid and Gregory, 1997; Gregory and Williams, 2000; Volk with de Acosta, 2004) show that the learning interaction can be two-way, involving a process that Gregory terms 'synergy', defined as 'a unique reciprocity whereby siblings act as adjuvants in each other's learning' (Gregory, 2001: 309).

Synergy between siblings arises from the older child's greater knowledge being practised and re-formulated in order to share it with the younger sibling, who plays their part as active audience and questioner (Gregory, 2001). Interactions with grandparents around the computer introduce the additional possibility that the younger generation may have greater facility in operating this new cultural artefact, whilst the older generation has more experience in literacy and other areas of learning, and thus both parties may have knowledge to share. Furthermore, if children are more familiar with the language in which the computer task is presented, and grandparents have relatively little knowledge of this but are more competent in the family's first 
language, once again this will affect the dynamics of the interaction. New insights into how 'synergy' can operate may thus be gained from investigating intergenerational computer activities, particularly in bilingual contexts.

\section{Collecting data}

The study began with a survey at a primary school in Tower Hamlets, East London, to ascertain what kinds of learning activities took place between 3-6 year old children and their grandparents. The survey was distributed to families with children of this age group who were thought by the school to have regular contact with grandparents. The school has a culturally mixed intake, with the two main linguistic groups being Sylheti/Bengali-speaking children from families of Bangladeshi origin (the largest group in the school), and monolingual English-speaking children, some from mixedrace families. 20 families answered the questionnaire, 17 Sylheti/Bengali-speaking and 3 monolingual English-speaking.

When answering the questionnaire, grandparents selected from a list of twenty possible activities in which they might engage with their grandchildren. 'Computer activities' was one of the items offered, but was mentioned by only two families, whereas most other items were noticeably more common. For example, 'going to the park' was selected by seventeen families, and 'storytelling' was selected by fourteen.

We then conducted case studies of nine families (six Sylheti/Bengali-speaking families and three English-speaking) through interviews and videorecording of learning events. From these families, eleven children were involved in our research, six bilingual in Sylheti/Bengali and English (Sahil, Sumayah, Anayet, Anayah, Amani, Abida) and five monolingual (siblings Lizzie and Sam, and Oscar and Cosmo, whose families were of UK white origin, and Steven whose maternal grandparents were from Guyana). Six were boys and five were girls. Four were in Year 1 (age six), four in Reception (age five) and three in nursery (age three to four).

We discovered that in the British Bangladeshi families, most of the grandparents and children did not use a computer at home. However, in Sahil's case, his father had installed a computer in the living-room specifically for the children's learning. Sahil was proficient at using it and sometimes showed his grandmother how to play computer games. Amongst the English-speaking children, Lizzie and her brother Sam used their family computer and shared computer activities with their grandmother when they visited her, and brothers Oscar and Cosmo also had a computer at home, as did their grandparents (although their grandmother said 'I don't keep up with computer games - they do that with their grandfather'). Steven's grandmother commented 'I don't know much about computers - we don't have one here, he has one at home'.

\section{Video-recording}

Families were asked to suggest typical activities that children and grandparents enjoyed doing together. For each family, two activities were video-recorded, such as cooking, gardening or storyreading, usually lasting around 15 minutes. We requested that one of these should be an activity involving the computer, and in cases where the family did not possess one, the researchers took a laptop to homes, enabling grandparents and children to explore a new learning tool in a familiar environment. The project was thus partly designed to investigate activities already occurring within families, and partly to investigate further possibilities for intergenerational exchange. 


\section{Multimodal video analysis}

In order to discover how learning interactions were conducted at the micro-level, the study took a multimodal approach to the analysis of videodata. The theory of multimodality developed by Kress and van Leeuwen (1996) emphasises the equal importance of semiotic modes such as the visual, gesture and action, as well as the verbal mode, to accomplish communication. Kress et al (2001) demonstrate the interplay of these modes in teaching and learning in secondary school science classrooms. Multimodal analysis is especially key when participants are engaged in interactive learning around the computer (Jewitt, 2003), since ideas are triggered by images as well as writing on the screen, gestures are used to focus joint attention on particular items, and actions are required to operate the programme.

Initial qualitative analysis of our videorecorded data suggested that touch might play an important role in intergenerational learning activities, including those around the computer, since children and grandparents often maintained close physical contact as they worked together. Gaze, at each other or at the screen, was another key aspect of communication. We therefore adopted a modified version of a transcription format developed by Lancaster to examine how a 23-month-old child and her father went about making a greetings card together (Lancaster, 2003). Our format includes columns for spoken language, gaze, and touch/action. In our data, touch and action were sometimes combined and sometimes used alone, so this column allows for both possibilities. Gesture, a specific type of action, is included in the same column.

Several extracts from each of two episodes of videodata will be analysed below: Anayah and her grandmother playing a numeracy game on the computer, and Lizzie and her grandmother searching for information on the internet. We will then consider how our findings relate to theoretical concepts introduced at the beginning of this paper, referring also to differences and similarities between these episodes and those recorded with other families in the project.

\section{Anayah and her grandmother: starting the computer game}

Six-year-old Anayah was from a British Bangladeshi family. She lived with her paternal grandparents (who were also her guardians), her father, an uncle and his wife, and a younger uncle who attended secondary school. Her grandmother, who played a particularly important role in her upbringing, had recently attended a family learning course for caregivers with English as a second language at Anayah's primary school. Anayah and her grandmother did not have a computer to use at home, so the researchers brought a laptop to the house. This was a new opportunity for Anayah's grandmother, whilst Anayah had a little experience from school.

In the extract below, Anayah and her grandmother begin to explore a computer game unfamiliar to both of them, so they need to pool resources to navigate their way through it. First they have to decide which activity to select from the choices offered by the 'Big Bus' game. Anayah's grandmother uses her English literacy skills to read some words off the screen: 'activities', 'information' and 'start activity', to help her granddaughter find out what is happening.

\section{Transcript 1: Anayah and her grandmother begin the 'Big Bus' game}


Spoken language appears in the first two columns.

Bengali is written in italics with English translation in brackets.

\begin{tabular}{|c|c|c|c|}
\hline Grandmother (GM) & Anayah (A) & Gaze & Touch/Action \\
\hline \multirow[t]{2}{*}{ Activities } & & $\begin{array}{l}\text { Both looking at } \\
\text { computer }\end{array}$ & $\begin{array}{l}\text { A - hand on mouse } \\
\text { GM smiling }\end{array}$ \\
\hline & Eh & $\begin{array}{l}\text { Both still looking at } \\
\text { computer }\end{array}$ & \\
\hline \multirow{2}{*}{$\begin{array}{l}\text { Eto lekha oi nu..(It's } \\
\text { written there) } \\
\text { information..start } \\
\text { activity }\end{array}$} & & & $\begin{array}{l}\text { GM pointing at screen } \\
\text { smiling, scrolls her finger } \\
\text { across screen }\end{array}$ \\
\hline & $\begin{array}{l}\text { Activity amrao } \\
\text { schoole khori } \\
\text { (We do activities in } \\
\text { school) }\end{array}$ & GM looks at $\mathrm{A}$ & \\
\hline $\begin{array}{l}\text { Khoro ni? Tho tae tomi } \\
\text { seno nai ni? } \\
\text { (Do you? Then you } \\
\text { know them don't you?) }\end{array}$ & & $\begin{array}{l}\text { GM looks back at } \\
\text { screen and then at the } \\
\text { researchers }\end{array}$ & GM smiles tenderly at A \\
\hline \multirow{4}{*}{$\begin{array}{l}\text { Tao amre hikho } \\
\text { (Then you teach me) }\end{array}$} & & GM looks at $\mathrm{A}$ & \\
\hline & $\begin{array}{l}\text { Ami beshi computero } \\
\text { zai na } \\
\text { (I don't go on the } \\
\text { computers much) }\end{array}$ & $\begin{array}{l}\text { They both look at } \\
\text { each other }\end{array}$ & $\begin{array}{l}\text { GM continuously smiles } \\
\text { at } A\end{array}$ \\
\hline & $\begin{array}{l}\text { Ami computero zai na } \\
\text { (I don't go on the } \\
\text { computer) }\end{array}$ & $\begin{array}{l}\text { A looks back at } \\
\text { computer }\end{array}$ & A smiles \\
\hline & $\begin{array}{l}\text { Zai na computero } \\
\text { (don't go to the } \\
\text { computer) }\end{array}$ & $\begin{array}{l}\text { GM looks back at A } \\
\text { for a few seconds }\end{array}$ & \\
\hline
\end{tabular}

The talk is mainly in Bengali as the matrix language, with English as the embedded language (Myers-Scotton, 1993). Bengali grammatical structures are used, with key English words fluently inserted into them. There are the words from the screen ('information, start activity') and Anayah's vocabulary from primary school ('activity', 'school' and 'computer').

Anayah recognises the word 'activity' when it is read out by her grandmother and states 'We do activities in school'. This prompts her grandmother to emphasise Anayah's status as a knowledgeable partner in the exercise ('Do you? Then you know them don't you?'), and she offers Anayah the chance to lead the activity ('Then you teach me'). However, Anayah seems unsure; she explains 'I don't go on the computers much', and emphasises this several times. This suggests Anayah has 
relatively little experience as yet of ICT at school, partly because she does not feel confident enough to 'go on the computers' when the chance is available.

Throughout the extract, there is a considerable amount of interaction between child and grandparent through gaze and smiling, an exchange that enables Anayah's grandmother to reassure her and encourages a feeling of mutuality as they tackle a task new to both of them. Although Anayah has been positioned as the main actor, and has control of the mouse, her grandmother is providing crucial support.

\section{Lizzie and her grandmother: starting up the internet}

Lizzie, aged six, came from a monolingual English-speaking family and lived with her younger brother and her parents. Her maternal grandmother lived in the countryside, over fifty miles from London, but saw her grandchildren every three weeks or so, and they often stayed with her. She had a computer at home that she sometimes used with the children, who also had access to educational games on their family's computer.

In this first extract, Lizzie and her grandmother are going on the internet to look for information about a moth they had found in the garden. They had already carried out a similar activity successfully on the grandmother's computer and were now repeating it on Lizzie's home computer to see if they could extend their knowledge. We can immediately see that Lizzie's grandmother is knowledgeable about using the internet, and that Lizzie positions herself as the user of the mouse.

\section{Transcript 2: Lizzie and her grandmother go on the internet}

\begin{tabular}{|c|c|c|c|}
\hline Grandmother (GM) & Lizzie (L) & Gaze & Touch/action \\
\hline $\begin{array}{l}\text { Well I thought it would be } \\
\text { nice to show Ruby < the } \\
\text { researcher> how we find } \\
\text { things out on the internet } \\
\text { so we really need } \\
\text { Freeserve Internet, that's } \\
\text { right, Freeserve Internet }\end{array}$ & & $\begin{array}{l}\text { L looks at } \\
\text { screen }\end{array}$ & $\begin{array}{l}\text { L bends over desk, } \\
\text { reaches for mouse }\end{array}$ \\
\hline Yes, you can press it, good & $\begin{array}{l}\text { I wanna press it, I } \\
\text { can press it }\end{array}$ & & $\begin{array}{l}\text { GM puts hand over L's } \\
\text { on mouse } \\
\text { GM moves hand away } \\
\text { L presses button }\end{array}$ \\
\hline
\end{tabular}

Lizzie does not need reassurance from her grandmother to start the activity, as Anayah did. However, despite being confident, she needs help in finding her way through the steps to reach the search engine. Her grandmother agrees that Lizzie can be the one to carry out the actions, but realises she may need assistance in moving the mouse accurately. Following the above exchange, Lizzie connects to the Internet with her grandmother's support, and navigates via 'Favourites' to reach Google. Her grandmother points at the screen to highlight the word 'Google' in the 'Favourites' list for Lizzie, and puts her hand over Lizzie's on the mouse to locate the cursor 
correctly on the screen and help her granddaughter to click in the right place. She then removes her hand and keeps it next to Lizzie's on the desk, 'shadowing' Lizzie's movements, ready to help again at any moment. The search engine is now ready to use, and the next excerpt shows Lizzie shifting the balance of interaction by deciding to pull out the keyboard and disputing the word that should be typed in.

Transcript 3: Typing 'moths' into the search engine

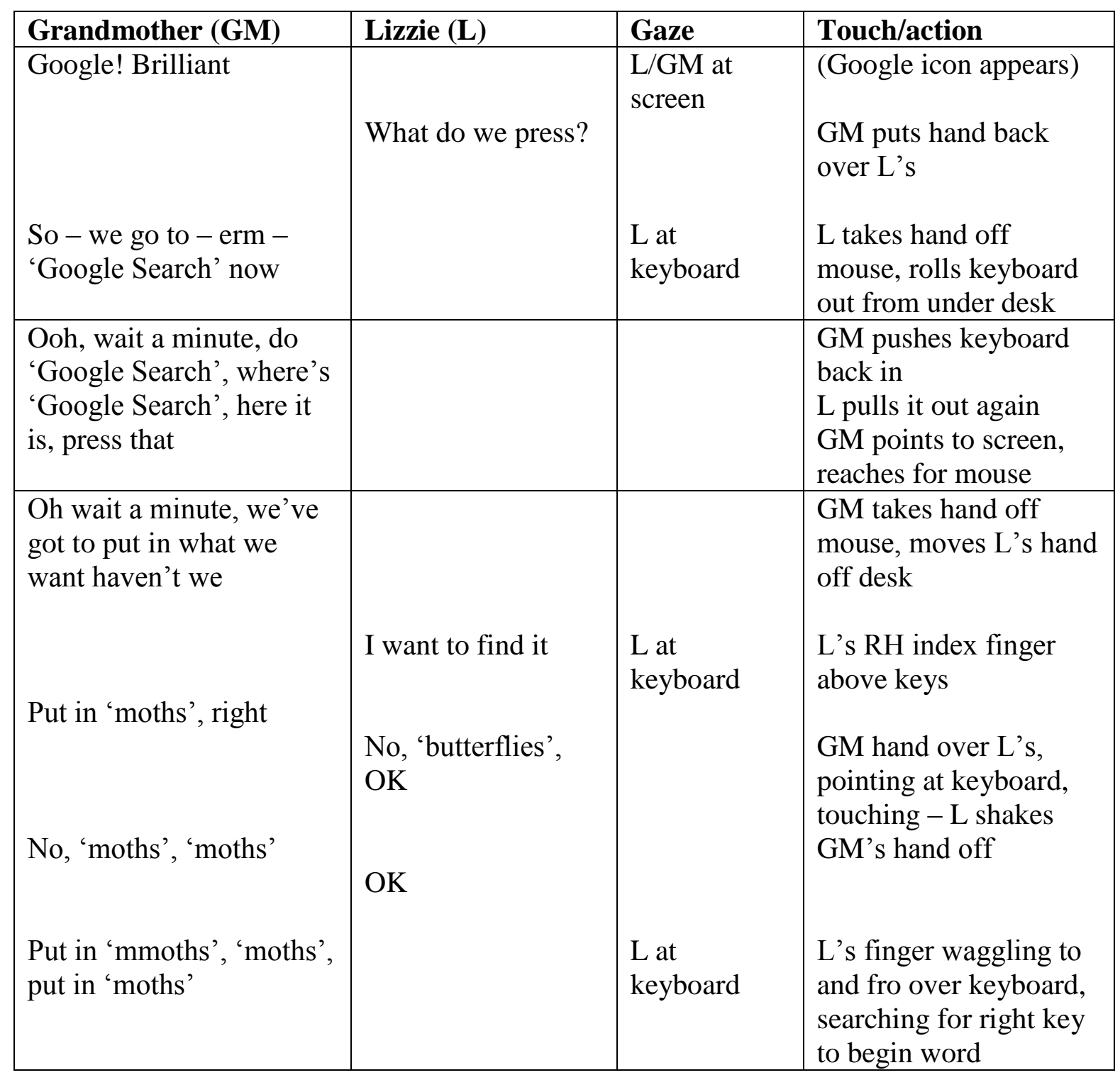

Although Lizzie asks what to press when the Google icon appears, she takes matters into her own hands by sliding out the keyboard because she knows that at this point it will be necessary to type words into the search engine. Meanwhile, her grandmother is focused on clicking on 'Google Search' and has not thought ahead to the need for the keyboard, so she slides the keyboard back in. Lizzie confidently pulls it back out again and her grandmother then belatedly realises that typing is the next step. This is a moment when Lizzie's conceptualisation of the stages of searching seems to operate more rapidly than her grandmother's. She is also determined to do the typing, and briefly contests the idea of searching for 'moths' by suggesting 'butterflies' instead. However, she accepts the original purpose of finding out about moths, and her 
grandmother starts to sound out the word by emphasising the first letter, 'mm'. During this verbal discussion, disagreement is also communicated physically by Lizzie's grandmother trying to position her granddaughter's hand in various ways and Lizzie resisting. By the end of the exchange, Lizzie has freed her hand and is poised ready to type.

Compared to the earlier analysis of Anayah and her grandmother setting out on their computer activity as joint explorers, these extracts show that Lizzie and her grandmother also collaborate but from a position where both have knowledge and confidence as computer users. A certain amount of contestation is communicated through verbal and physical modes, although they also share skills; Lizzie's grandmother supports her in finding 'Google' and Lizzie produces the keyboard to use the search engine. Gaze is jointly focused on the screen, since both participants are anticipating familiar signs that will determine the next step, whereas Anayah and her grandmother used gaze to focus on each other and build confidence for an unknown enterprise.

We now consider how each grandparent/grandchild partnership negotiates the task itself: in the case of Anayah and her grandmother, playing the numeracy game, and for Lizzie and her grandmother, finding information about a particular moth.

\section{Anayah and her grandmother: playing the counting game}

The activity selected by Anayah and her grandmother from the 'Big Bus' menu is designed to develop the concept of counting. First, seven pictures of flowers appear on the screen. Anayah realises she has to count them and does so. Her grandmother reinforces the learning by saying 'seven flowers'. However, they are not sure what to do next, so one of the researchers advises them to click on the number seven in the row of numbers shown at the bottom of the screen.

In the extract presented below, Anayah and her grandmother now know how to do the activity. This time they see six pictures of seals on the screen.

\section{Transcript 4: Counting 'six seals'}

$<$ ? $>$ indicates uncertain transcription.

\begin{tabular}{|c|c|c|c|}
\hline Grandmother (GM) & Anayah (A) & Gaze & Touch/action \\
\hline $\begin{array}{l}\text { Oi tho oi zani khita, } \\
\text { egu etar nam khita? } \\
\text { (Oh that what is that, } \\
\text { what's the name of } \\
\text { that?) }\end{array}$ & & Both look at screen & $\begin{array}{l}\text { GM points to screen with } \\
\text { unsure expression } \\
\text { A has index finger in } \\
\text { mouth with a thoughtful } \\
\text { expression }\end{array}$ \\
\hline & $\begin{array}{l}\text { Ami zani na } \\
\text { (I don't know) }\end{array}$ & Both look at screen & A puts hands under table \\
\hline $\begin{array}{l}\text { Englishe khita khoi? } \\
\text { Zani na eta...seal...na } \\
\text { khita } \\
\text { (What is it called in } \\
\text { English? don't know }\end{array}$ & $<$ Suxi?> I think & & A shrugs her shoulders \\
\hline
\end{tabular}




\begin{tabular}{|l|l|l|l|}
\hline $\begin{array}{l}\text { what...seal...or } \\
\text { something) }\end{array}$ & & & and purses her lips \\
\hline Six & $1,2,3$, & \\
$4,5,6$ & $4,5,6$ & $\begin{array}{l}\text { A counts, pointing at } \\
\text { each picture on screen }\end{array}$ \\
Six seals! & I wanna press & $\begin{array}{l}\text { A puts her hand back on } \\
\text { mouse }\end{array}$ \\
\hline
\end{tabular}

Anayah's grandmother initiates the task by asking Anayah 'What's the name of that?' (referring to the animal they can see on the screen, the seal). If this event was taking place with an English-speaking parent or in a classroom, the adult would already know the answer, and would be using the question to check the child's knowledge. In this case, however, it is a genuine question from Anayah's grandmother. She is not sure of the answer, and Anayah is equally likely to know it, since both of them are learners of English. In fact, Anayah says she does not know, so her grandmother reiterates the question and suggests her own answer:'seal...or something'. She sounds unsure, probably because she is reading the word off the screen but it is not familiar to her.

Anayah says a word which might be her guess at 'seal', but sounds rather like 'six'. Her grandmother re-affirms the idea of 'six' and Anayah confidently counts to six, pointing at each picture on the screen as she does so. She is using the method of oneto-one correspondence, which is probably how she currently handles the concept of counting. Her grandmother supports the idea by joining in with Anayah's counting, and then saying 'Six seals!' This is a reinforcement of English vocabulary for both of them, as well as reinforcing the mathematical concept for Anayah's benefit.

Anayah then says 'I wanna press' - in English, probably because she knows the word 'press' from school (though later it turns out that she knows the word in Bengali as well). She is trying to click on 'six' at the bottom of the screen, but this seems to take some time. Perhaps she is having difficulty with placing the arrow on the right spot so that she can click on the number. This demands a certain amount of skill in handling the mouse, a skill that Anayah is still acquiring.

Transcript 5: Completing the 'seal' task

\begin{tabular}{|c|c|c|c|}
\hline Grandmother (GM) & Anayah (A) & Gaze & Touch/action \\
\hline Catch a six here & & GM and $\mathrm{A}$ at screen & $\begin{array}{l}\text { GM points to bottom of } \\
\text { screen and scrolls her } \\
\text { finger across screen }\end{array}$ \\
\hline $\begin{array}{l}\text { Seals na khita (seals or } \\
\text { something) } \\
\text { S..E..A..L }\end{array}$ & Yah ...six & & $\begin{array}{l}\text { A moves mouse around } \\
\text { GM looks away from } \\
\text { screen, she pulls hand } \\
\text { away and wipes her } \\
\text { forehead }\end{array}$ \\
\hline & Should I press the $6 ?$ & $\begin{array}{l}\text { A looks at GM } \\
\text { GM looks back at }\end{array}$ & \\
\hline
\end{tabular}




\begin{tabular}{|l|l|l|l|}
\hline & & screen & \\
\hline Mm-hmm & $\begin{array}{l}\text { A has a look of } \\
\text { concentration }\end{array}$ & \\
\hline How many seals? & $1,2,3,4,5,6$ & & $\begin{array}{l}\text { Counts by pointing her } \\
\text { finger at the screen }\end{array}$ \\
\hline Next & & & $\begin{array}{l}\text { GM points to right hand } \\
\text { corner of the screen }\end{array}$ \\
\hline & Arrow...arrow...arrow & & \\
\hline
\end{tabular}

The words 'six seals catch a six' have appeared on the screen, and Anayah's grandmother encourages her to go ahead by reading out part of this phrase, saying 'Catch a six here' as she points to the screen. She waits patiently while Anayah is manoeuvring the mouse. In the meantime she explores the spelling of the word 'seal''S..E..A..L', a verbal repetition that will benefit Anayah as well.

Anayah is wondering why nothing has happened and seeks her grandmother's gaze for support. She also asks for advice verbally, saying 'Should I press the 6?' This is a relatively sophisticated way of phrasing a question, using the modal verb 'should', and it is the kind of language that her grandmother might be learning by interacting with Anayah, thus adding to her own repertoire of understanding in English.

She responds to Anayah's query by saying 'Mm-hmm' - a supportive answer, affirming her granddaughter's aim rather than taking over from her as the main actor. She then revises the information that is still on the screen by asking 'How many seals?' and Anayah counts to six again.

To reach a new task, you have to click on 'next' and Anayah's grandmother prompts her to do this, pointing at the relevant place on the screen. Anayah manages to position the cursor correctly and they continue to go through the number tasks together for a while.

\section{Lizzie and her grandmother: finding the right moth}

Once Lizzie has agreed to type the word 'moths' into the search engine and begun with the letter ' $M$ ', her grandmother continues to help with the spelling, prompting her with 'O', and then 'something else', which Lizzie correctly decides to be 'T'. She asks 'What comes after T?' and her grandmother supplies ' $H$ ' and ' $S$ '. She then directs Lizzie to 'go to Google Search' and Lizzie clicks on those words, bringing up a list of sites.

\section{Transcript 6: Choosing and exploring the site}

\begin{tabular}{|c|c|c|c|}
\hline Grandmother (GM) & Lizzie (L) & Gaze & Touch/action \\
\hline $\begin{array}{l}\text { 'Moths', 'butterflies and } \\
\text { moths', now wait a minute } \\
\text { Erm...here - try that one, } \\
\text { yeah, try that one }\end{array}$ & This one, this one & $\begin{array}{l}\mathrm{L} / \mathrm{GM} \text { at } \\
\text { screen }\end{array}$ & $\begin{array}{l}\text { L moves mouse } \\
\text { GM hand to mouth, then } \\
\text { points with little finger to } \\
\text { screen }\end{array}$ \\
\hline & Shall I press here? & $\mathrm{L} / \mathrm{GM}$ at & L moves mouse \\
\hline
\end{tabular}




\begin{tabular}{|c|c|c|c|}
\hline $\begin{array}{l}\text { Yeah, press that one, 'cos see } \\
\text { what that says, 'cos that first } \\
\text { one is 'North American } \\
\text { moths', it might not have this } \\
\text { one } \\
\text { Of course a lot of these sites } \\
\text { are American ones aren't they }\end{array}$ & & screen & $\begin{array}{l}\text { L clicks } \\
\text { (heading appears on } \\
\text { screen 'Butterflies and } \\
\text { moths', menu down LH } \\
\text { side, then two pictures, } \\
\text { small one and larger one } \\
\text { below) }\end{array}$ \\
\hline $\begin{array}{l}\text { No there's a moth } \\
\text { Yes you're quite right, yes, } \\
\text { and that's a butterfly, you're } \\
\text { right }\end{array}$ & $\begin{array}{l}\text { What if I <?> } \\
\text { I think that's a } \\
\text { moth and that - } \\
\text { I said that's a moth } \\
\text { (laughs) }\end{array}$ & & $\begin{array}{l}\text { L points to lower picture } \\
\text { then upper one } \\
\text { GM points to lower } \\
\text { picture } \\
\text { L touches GM's arm } \\
\text { which is leaning over her }\end{array}$ \\
\hline $\begin{array}{l}\text { (commenting in mutters about } \\
\text { what can see on screen) } \\
\text { Now let's have a look, let's } \\
\text { see what it might be }\end{array}$ & & $\begin{array}{l}\mathrm{L} / \mathrm{GM} \text { at } \\
\text { screen }\end{array}$ & $\begin{array}{l}\text { L puts both arms around } \\
\text { GM's which are now } \\
\text { both leaning on desk, so } \\
\text { L encircles GM's arms } \\
\text { and leans head on inside } \\
\text { of GM's right arm, rubs } \\
\text { cheek up and down GM's } \\
\text { arm }\end{array}$ \\
\hline $\begin{array}{l}\text { Erm... } \\
\text { 'Moth index', let's go down to } \\
\text { the 'Moth index', press that } \\
\text { one }\end{array}$ & Do - er - that one & $\begin{array}{l}\mathrm{L} / \mathrm{GM} \text { at } \\
\text { screen }\end{array}$ & $\begin{array}{l}\text { L takes mouse } \\
\text { GM puts hand over L's } \\
\text { to position mouse, L/GM } \\
\text { click, GM removes hand } \\
\text { and keeps it alongside }\end{array}$ \\
\hline
\end{tabular}

Lizzie suggests a site, but her grandmother helps her choose the site most likely to yield information about the particular moth they are looking for. This is a complex literacy task requiring a rapid assessment of visual and verbal information about the potential sites offered, and Lizzie's grandmother uses her greater world experience to decide that a British site will be more relevant than a North American one. Lizzie clicks on that site, and pictures of both a butterfly and a moth then appear.

Lizzie correctly identifies the lower picture as a moth but then points to the other picture, so her grandmother temporarily disagrees and Lizzie has to reaffirm her original choice. They re-establish harmony verbally (by her grandmother saying 'you're quite right') and through laughter and touch on Lizzie's part. Though both continue to gaze at the screen, Lizzie confirms her trust in their relationship by rubbing her cheek affectionately against her grandmother's arm as the latter considers 
which part of the site to visit next. Lizzie once again makes her own suggestion and takes hold of the mouse, but her grandmother decides they need to look through the 'Moth index'. Lizzie accepts having her grandmother's hand on the mouse over hers, and they jointly click to reach the index.

Subsequent to this extract, a list of moths appears and again Lizzie puts forward a choice, saying 'This one?' Her grandmother offers her greater knowledge once more, but without being directive: 'Erm, no, because it was a daytime moth and I think that's a night moth 'cos it's got 'Noct' like 'Nocturnal', doesn't it'. Together they move the mouse up and down the list, searching for the most likely moth, and eventually Lizzie's grandmother suggests looking in their scrapbook, where they already have the Latin name on a printout from their previous internet search. She helps Lizzie find the species 'Lasiocampidae' and the specific type of moth 'Quercus' on the screen, and points out that the photograph on this site is the same as the one they found previously. She has thus assisted Lizzie in accomplishing a search which a six-year-old could not have performed unaided, just as Anayah's grandmother enabled her granddaughter to play a numeracy game that she would not have understood alone.

Both computer episodes finish with an interesting reversal of roles. Below we discuss how and why Anayah and Lizzie each begin to take the lead.

Anayah shows her grandmother how to use the mouse

Transcript 7: 'You have to press it'

\begin{tabular}{|c|c|c|c|}
\hline Grandmother (GM) & Anayah (A) & Gaze & Touch/action \\
\hline & $\begin{array}{l}\text { Tomi maro } \\
\text { (you press) }\end{array}$ & Both look at screen & $\begin{array}{l}\text { A hands over mouse to } \\
\text { GM and strokes her own } \\
\text { forehead }\end{array}$ \\
\hline & $\begin{array}{l}\text { Count...count khoro } \\
\text { (You count) } \\
\text { Count khoro! } \\
\text { (You count!) }\end{array}$ & $\begin{array}{l}\text { Both looking at } \\
\text { screen }\end{array}$ & $\begin{array}{l}\text { GM takes hold of mouse } \\
\text { at an angle }\end{array}$ \\
\hline $\begin{array}{l}\text { Ami ni? (Me?) } \\
\text { (laughs) }\end{array}$ & & GM looks at $\mathrm{A}$ & \\
\hline \multirow[t]{2}{*}{$1,2,3,4,5,6,7,8,9$} & $\begin{array}{l}\text { A counts along } \\
\text { quietly with GM }\end{array}$ & & $\begin{array}{l}\text { GM takes her hand off } \\
\text { mouse and counts with } \\
\text { finger on screen }\end{array}$ \\
\hline & $\begin{array}{l}\text { Ono press khoro } \\
\text { (press here) }\end{array}$ & $\begin{array}{l}\text { GM looks down at } \\
\text { mouse and back at } \\
\text { screen } \\
\text { A looks at GM and } \\
\text { back at screen }\end{array}$ & $\begin{array}{l}\text { A points to screen } \\
\text { showing where GM } \\
\text { should place the arrow }\end{array}$ \\
\hline \multirow[t]{2}{*}{$\begin{array}{l}\text { Khilan dekho te } \\
\text { (show me how) }\end{array}$} & & GM looks at mouse & \\
\hline & Oitu iota naini & & A shows GM on mouse \\
\hline
\end{tabular}




\begin{tabular}{|l|l|l|l|}
\hline & $\begin{array}{l}\text { okhano press khor tai } \\
\text { (that you know that } \\
\text { you have to press it) }\end{array}$ & $\begin{array}{l}\text { with her finger where to } \\
\text { press }\end{array}$ \\
\hline $\begin{array}{l}\text { okhano? } \\
\text { (here?) }\end{array}$ & & & $\begin{array}{l}\text { A puts her hand over } \\
\text { GM's and presses }\end{array}$ \\
\hline & $\begin{array}{l}\text { Oi } \\
\text { (yes) }\end{array}$ & & \\
\hline
\end{tabular}

As Anayah pushes the mouse over to her grandmother, she says 'you press' in Bengali. She also tells her grandmother to do the task, repeating 'you count!', each time saying 'count' in English since it is a word she knows from school. Codeswitching into English also has the effect of emphasising her directive (Gumperz, 1982). Her grandmother checks the role change, asking 'me?' and simultaneously looking at Anayah for confirmation, whilst also showing surprise through laughter. She does the counting in the same way that Anayah did, pointing to each picture on the screen as she counts to nine. Her granddaughter accompanies her in the counting, but quietens her voice to let her grandmother take the lead.

Anayah then tells her grandmother to 'press here', this time highlighting 'press' in English, and underlines her verbal instructions through gesture and gaze, indicating where the cursor needs to be placed on the screen and looking at her grandmother to engage her in this action. However, her grandmother is not confident about using the mouse, so she asks 'show me how'.

This time Anayah demonstrates how to use the mouse through action, accompanied with verbal instructions in Bengali. She tries to guide her grandmother's hand and help her finger make the click at the right moment. Controlling the mouse and making the click is difficult for the grandmother because her hand and fingers are not accustomed to making this movement and co-ordinating it with the visual checking of the screen.

Anayah realises this and, as the episode continues, spends some time trying to help, at one point massaging her grandmother's finger affectionately during the activity. Here Anayah shows the same kind of patience that her grandmother offered her earlier. Meanwhile her grandmother continues to ask for instructions: 'show me where I am supposed to press'. Finally, Anayah comments 'that's OK', confirming that the arrow is now in the right place on the screen. However, she decides to take control of the mouse and make the click because her grandmother is still having difficulty, saying 'here let me do it for you'.

\section{Lizzie decides to investigate a different moth}

\section{Transcript 8: 'I want to print it though'}

\begin{tabular}{|l|l|l|l|}
\hline Grandmother (GM) & Lizzie (L) & Gaze & Touch/action \\
\hline $\begin{array}{l}\text { Yeah, but it wasn't that one, } \\
\text { it's this one }\end{array}$ & $\begin{array}{l}\text { Can we print it, can } \\
\text { we print it? }\end{array}$ & $\begin{array}{l}\text { L/GM at } \\
\text { picture of } \\
\text { moth on } \\
\text { screen } \\
\text { though }\end{array}$ & $\begin{array}{l}\text { GM puts hand over } \\
\text { mouse }\end{array}$ \\
\hline
\end{tabular}




\begin{tabular}{|l|l|l|l|}
\hline $\begin{array}{l}\text { Wait a minute, I'm not sure - } \\
\text { get that one that we did } \\
\text { actually find } \\
\text { That one, 'cos I found it on } \\
\text { another website didn't I, last } \\
\text { time we did it }\end{array}$ & & $\begin{array}{l}\text { GM clicks over L's } \\
\text { hand on menu and } \\
\text { removes her hand }\end{array}$ \\
$\begin{array}{l}\text { There you go, that's what it } \\
\text { was } \\
\text { They've used the same } \\
\text { photograph (laughs), they } \\
\text { probably use them for all the } \\
\text { different websites }\end{array}$ & $\begin{array}{l}\text { L double-clicks on } \\
\text { same spot (picture of } \\
\text { 'Quercus' moth is } \\
\text { already coming up) }\end{array}$ \\
\hline $\begin{array}{l}\text { Where does it say 'Print'? You } \\
\text { know, it's your machine }\end{array}$ & This one & $\begin{array}{l}\text { Where's the 'Print'? } \\
\text { screen }\end{array}$ & $\begin{array}{l}\text { Lat hand on mouse } \\
\text { GMoves it with L, takes } \\
\text { hand off } \\
\text { L double-clicks }\end{array}$ \\
Wait a minute - there it goes & $\begin{array}{l}\text { I always jump up } \\
\text { when I hear it print }\end{array}$ & $\begin{array}{l}\text { L looks to } \\
\text { side }\end{array}$ & $\begin{array}{l}\text { L jumps up on chair to } \\
\text { see page coming out of } \\
\text { printer }\end{array}$ \\
\hline
\end{tabular}

Lizzie wants to print out the first picture that appears on the screen when she clicks on the name of the moth species 'Lasiocampidae' in response to her grandmother's prompt. Her grandmother wants to keep to the original task, which is to find the 'Quercus' moth. Lizzie disputes this by saying 'I want to print it though' (referring to the current picture), but her grandmother moves the mouse to click on the name 'Quercus' on the menu. Although Lizzie accepts her grandmother's decision, she has demonstrated her desire to go beyond the limits of their planned investigation and exploit the possibilities of hypertext.

Lizzie is familiar with the sequence of commands to print material from the internet and knows she has to find the 'Print' icon on the screen. She checks its whereabouts with her grandmother, who points out that Lizzie is the expert on this computer, and in fact she has already identified it correctly. She then climbs up on a chair so that she can reach the printer, which is on a shelf above the desk, to see the printed page immediately.

This extract shows Lizzie's eagerness to follow different paths of inquiry offered by the internet, which would introduce new areas of learning both for her and for her grandmother. She also acts confidently when printing out material. In fact, her grandmother stated that she was less confident about word processing than her grandchildren, 'but now that Lizzie is learning at school, hopefully she'll teach me'. So whilst adult support is key to Lizzie navigating through the steps of this internet search, she also has knowledge to share with her grandmother in their joint accomplishment of the task. 
We will now relate these findings, and others from the research project, to theoretical ideas discussed earlier about young children learning through ICT.

\section{Differences between families}

Whilst both episodes presented above indicate the potential of ICT for early learning when mediated by adult support, the first impression might be that Lizzie's computer activity with her grandmother is more complex than Anayah's one. Indeed, the opportunity to use the internet for research opens up new worlds of information beyond that of a simple counting game. Lizzie's grandmother was able to provide support for this activity partly because the internet operates mainly through English, and partly because she had her own computer and understood internet search procedures. In comparison, Anayah's grandmother was unfamiliar with computers and Anayah's only experience came from school, whilst Lizzie had the advantage of access to a computer at home.

The 'digital divide' therefore rears its head as a potential disadvantage for Anayah. As mentioned earlier, most of the British Bangladeshi grandparents and children did not use a computer at home. However, our research project - in which every child and grandparent had the opportunity to try a computer activity through the provision of a laptop where needed - indicates the potential for intergenerational learning around the computer, even where the participants had little or no prior experience. The multimodal analysis employed reveals similarities as well as differences between families in the ways that children and grandparents jointly approached computer tasks.

\section{Similarities between families \\ Structuring the activity and focusing attention}

The detailed examination of how grandparents and children communicated - through gaze, touch and action as well as verbally - shows how each grandparent, sitting quietly beside their grandchild at the computer, played an important role similar to that of Lizzie's grandmother. Through their presence they helped to structure the event, firstly by establishing with the child what task she or he wanted to do. For example, Anayet's grandmother suggested the activity of typing his name, just as Anayah's grandmother helped her select from a menu of educational games.

The grandparent then ensured that the stages of the activity were accomplished. Amani's grandmother did not touch the keyboard, but pointed to particular keys when Amani needed help with spelling her name. Anayet's grandmother also used the gesture of pointing, both to the general area of the keyboard and to a specific key, to support her grandson's search for each letter. She reminded him of the sequence of letters needed by using prompts such as 'khonta first?' (what's first?), 'A...N aibo naini?' (A...N next isn't it?) and 'Y tomi bair khoro sai?' (Y - can you find it?). Like Anayah's grandmother, she embedded salient English words or letters in Bengali utterances to maximise understanding. In this case Anayet's grandmother was confident about spelling in English, but grandparents could also follow the sequence of an activity even if they were not initially familiar with it, as shown by Anayah's grandmother prompting her to count the pictures of seals on the screen and click on 'next' in order to obtain another question in the game. 
Children's concentration was maintained throughout the activities by interaction with grandparents. As well as pointing at the screen, grandparents established joint attention through gaze and action. Anayet's grandmother emphasised her queries about spelling by looking directly at her grandson, and rewarded him with a smile when he found the correct letter. Sam, Lizzie's younger brother, was kept on task in a lengthy computer game about different forms of transport by his grandmother encircling him with her arms as he sat on her knee, and patting his stomach whilst she also focused her gaze on him.

\section{Concepts of print and concepts of screen}

These young children were often reliant on grandparents' literacy knowledge and wider cultural knowledge to navigate through a task. Steven's grandmother and Abida's grandfather helped their grandchildren explore an unfamiliar game by reading what was happening on the screen and working out how the game might operate. In Steven's case, he had a computer at home but was using the research project laptop for the first time at his grandmother's house, so he needed the extra support of her suggestions. Anayah's grandmother understood prompts such as 'start activity' and 'how many seals?' in the counting game, whilst Lizzie's grandmother read out the relevant commands to reach the internet search engine and the menu of information about moths, as described above.

With regard to concepts of screen, some children were more confident than their grandparents and were passing on new cultural knowledge in this area, as Anayah did by showing her grandmother how to use the mouse. Sahil also placed his hand on top of his grandmother's to guide her in moving the mouse and clicking. Abida's grandfather was the only Bangladeshi grandparent who seemed to have had previous experience of computers and was accustomed to using a mouse. Amongst the grandparents of UK origin, Oscar's grandmother commented 'I find the mouse awkward - they've been brought up with it'. Lizzie's grandmother, as we saw earlier, was proficient with the mouse and guided her grandchildren's hands when she felt it was necessary. Since Lizzie was a capable user of the mouse, this was generally to ensure that the cursor was positioned on the correct command, whilst three-year-old Sam needed help with 'dragging and dropping', a technique he was still learning. However, Lizzie and Sam felt they also had technological knowledge to share with their grandmother; she commented 'both try to teach me how to use the computer'.

\section{Sustained shared thinking and collaborative talk}

The co-construction of learning can be seen to be occurring for both Anayah and Lizzie with their grandparents, and the multimodal transcripts reveal that this process took place through gesture and gaze as well as verbally. Anayah's grandmother spelled out the new word 'S..E..A..L' for herself and her granddaughter and counted together with Anayah in English to establish how many items they could see on the screen, supported by scrolling their fingers across the respective words or pictures. At times when they were unsure what to do, they asked questions of each other whilst simultaneously engaging the other's gaze. Lizzie's grandmother verbalised her thinking on which website to choose so that she shared the reasons for her decision with her granddaughter, and through pointing and talk they identified which picture represented a moth and which a butterfly. Lizzie then waited whilst her grandmother debated where to find the particular moth they were seeking, communicating her support for this thinking process by rubbing her cheek against her grandmother's arm. 
Bilingual children and grandparents made use of resources in Sylheti/Bengali as well as English for collaborative talk. They drew on both languages to maximise joint understanding, and also used code-switching to gain their co-participant's attention, negotiate ideas and place emphasis. For example, when Anayah handed over the mouse to her grandmother she gave her first instruction in Bengali ('tomi maro' 'you press') but then switched into English to emphasise the need to press: 'ono press khoro' ('press here'). Similarly, Anayet's grandmother code-switched into English when helping him to spell his name, highlighting the concepts used ('name', 'letter') and signalling the sequence of steps to take ('first', 'which one').

\section{Guided participation and synergy}

Rogoff's concept of children learning through 'guided participation' includes an active role for the child 'apprentice' as well as the caregiver, since she argues that 'guided participation is jointly managed by children and their companions in ways that facilitate children's growing skills' (Rogoff, 1990: viii). However, the emphasis is still on the acquisition of skills from the children's side. Intergenerational computer activities seem, rather, to exhibit a reciprocal learning exchange that accords more closely with the concept of 'synergy' identified by Gregory (2001).

In most of the families involved in our research, children had more experience of working on the computer than did their grandparents. When the grandparents of Steven, Anayah, Amani and Anayet had their first opportunity to work with their grandchildren on the laptop provided by the research project, they let the children take the central role of operating the mouse and using the keyboard. Meanwhile, the grandparents encouraged exploration, made suggestions for what to do next, and helped with issues such as spelling. Each participant in the child-grandparent dyad thus brought their own strengths to the activity in a relatively equal exchange.

The balance was somewhat different in other dyads. Abida's grandfather had ICT experience as well as literacy knowledge, so had greater overall competence than Abida did. Lizzie's grandmother was more confident and knowledgeable about internet use than her granddaughter. In another case, it was the child who took the lead in both technological skills and subject matter; Sahil, who was accustomed to using the family computer, showed his grandmother how to play the game 'Solitaire' and guided her hand on the mouse. However, in each of these cases there were further factors involved: Abida was developing a knowledge of English that would soon outstrip that of her grandfather, Lizzie was doing the same with word processing skills, and Sahil's grandmother brought to the task her knowledge of playing card games in Bangladesh. The intergenerational learning exchange or 'synergy' was therefore a dynamic process liable to shift as participants gained new linguistic and cultural competences.

\section{Mutuality}

In all the interactions we observed between children and grandparents, knowledge and skills were shared sensitively in an atmosphere of warmth and trust. Synergy was aided by the grandchild/grandparent relationship being based on 'mutuality', in which the younger and older generations provided for each other's needs in terms of care and companionship (for a more extensive discussion of this concept, see Kenner et al, 
2007). The strengths and vulnerabilities of young children and the elderly

complemented one another, particularly with regard to activities around the computer.

Although grandparents possessed greater world knowledge in many areas, they recognised their dependence on the technological help of their grandchildren. As Oscar and Cosmo's grandmother commented: 'with computers, they're far more advanced than we are - if you've got a problem they go click and click'. Sahil's grandmother said 'They introduce me to new things and new ways', giving as an example 'Sahil shows me how to play cards on the computer - I really found it fascinating'. Anayet's grandmother established his role as key actor with regard to what was happening on the screen by saying 'I can't see - you have the eyes'. Her statement acknowledged the physical vulnerability of the older generation and also emphasised the knowledge and understanding of new technology possessed by the young child in comparison to the grandparent; it is children who have the power to see into the future. At the same time, Anayet's learning - like that of other children participating in the research - benefited considerably from his grandmother's subtle support in their joint computer activity.

\section{Conclusion}

Examining the role of the computer in intergenerational learning has highlighted its potential as a cultural tool encouraging interactivity and exploration of knowledge, made accessible to both generations by mutual collaboration. In this research project, particularly in British Bangladeshi families, grandparents were often aided in computer activities through the expertise of their grandchildren. Meanwhile, young children needed the support of their grandparents to structure the learning event, maintain concentration and accomplish tasks relying on linguistic and cultural knowledge.

For several grandparents involved in the project, this was their first opportunity to work with computers, and during the activity they showed a growing interest in what was happening on the screen. Their curiosity indicated a potential to develop knowledge and expertise if they were to have ongoing access to the technology. For Bangladeshi grandparents, this would particularly be the case if they were provided with software or access to websites operating in Bengali. They could then more easily develop skills in word processing and internet searches, as Lizzie's grandmother had been able to do in English.

The research findings therefore have important implications for educators, both in the community sector and in mainstream schools. If opportunities can be provided for grandparents and grandchildren to work together around the computer, for example through family learning courses involving ICT and including bilingual resources where necessary, this could lead to positive outcomes for both the younger and older generations. In particular, the role of grandparents in bilingual families could be of considerable importance in facilitating young children's learning through new technologies.

\section{Acknowledgements}

Our thanks go to the families who participated in the research project, and to Hermitage Primary School. 
This research was funded by the ESRC (Award R000220131).

\section{*Note}

Sylheti is an oral language from the area of Sylhet in Bangladesh. This was the language spoken by most of the families in the study, with Standard Bengali being used in writing. Some families also spoke varieties of Bengali and thus we have adopted the term Sylheti/Bengali to cover the range of languages used.

\section{References}

BECTa (British Educational Communications and Technology Agency) (2002) ImpaCT2: The Impact of Information and Communication Technologies on Pupil Learning and Attainment. Annesley, Notts: Department for Education and Skills.

BECTA (2003) Primary Schools - ICT and Standards. www.partners.becta.org.uk/index.php?section=rh\&rid=11231

Crook, C. (2001) The social character of knowing and learning: implications of cultural psychology for educational technology. Journal of Information Technology for Teacher Education 10 (1-2), 19-36.

Davies, N. (2004) Not just how but why: EAL and ICT in the multilingual classroom. NALDIC Quarterly, 1(4), 12-19.

Fatouros, C. (1995) Young children using computers: planning appropriate learning experiences. Australian Journal of Early Childhood 20 (2), 1-6.

Giacquinta, B., Baucer, A. and Levin, J. (1993) Beyond Technology's Promise. Cambridge: Cambridge University Press.

Goodison, T. (2002) ICT and attainment at primary level. British Journal of Educational Technology 33 (2), 201-211.

Gregory, E. and Williams, A. (2000) City Literacies. London: Routledge.

Gregory, E. (2001) Sisters and brothers as language and literacy teachers: synergy between siblings playing and working together. Journal of Early Childhood Literacy 1 (3), 301-322.

Gumperz, J. (1982) Discourse Strategies. Cambridge: Cambridge University Press.

Haugland, S. (2000) Early childhood classrooms in the $21^{\text {st }}$ century: using computers to maximize learning. Young Children 55 (1), 12-18.

Jessel, J., Arju, T., Gregory, E., Kenner, C. and Ruby, M. (2004) Children and their grandparents at home: a mutually supportive context for learning and linguistic development. English Quarterly 36 (4), 16-23. 
Jewitt, C. (2003) Computer-mediated learning: the multimodal construction of mathematical entities on screen. In Jewitt, C. and Kress, G. (eds) Multimodal Literacy. New York: Peter Lang.

Kenner, C., Ruby, M., Gregory, E., Jessel, J. and Arju, T. (2007) Intergenerational learning between children and grandparents in East London. Journal of Early Childhood Research 5 (2), 219-243.

Kress, G. and van Leeuwen, T. (1996) Reading Images: The Grammar of Visual Design. London: Routledge.

Kress, G., Jewitt, C., Ogborn, J. and Tsatsarelis, C. (2001) Multimodal Teaching and Learning: The Rhetorics of the Science Classroom. London: Continuum Press.

Labbo, L. and Reinking, D. (2003) Computers and early literacy education. In Hall, N., Larson, J. and Marsh, J. (eds) Handbook of Early Childhood Literacy. London: Sage.

Lancaster, L. (2003) Beginning at the beginning: how a young child constructs time multi-modally. In Jewitt, C. and Kress, G. (eds) Multimodal Literacy. New York: Peter Lang.

Myers-Scotton, C. (1993) Duelling Languages: Grammatical Structure in CodeSwitching. Oxford: Oxford University Press.

Rashid, N. and Gregory, E. (1997) Learning to read, reading to learn: the importance of siblings in the language development of young bilingual children. In Gregory, E. (ed) One Child, Many Worlds: Early Learning in Multicultural Communities. London: David Fulton.

Rogoff, B. (1990) Apprenticeship in Thinking. New York: Oxford University Press.

Rogoff, B. (2003) The Cultural Nature of Human Development. New York: Oxford University Press.

Siraj-Blatchford, J. (ed) (2004) Developing New Technologies for Young Children. Stoke-on-Trent: Trentham Books.

Siraj-Blatchford, J. and Whitebread, D. (2003) Supporting Information and Communications Technology in the Early Years. Maidenhead, Berks: Open University Press.

Siraj-Blatchford, J. and Siraj-Blatchford, I. (2004) IBM KidSmart Early Learning Programme European Evaluation Report: France, Germany, Italy, Portugal, Spain and UK, Final Report. Basingstoke: IBM.

Siraj-Blatchford, I. and Siraj-Blatchford, J. (2005) A Guide to Developing the ICT Curriculum for Early Childhood Education. Stoke-on-Trent: Trentham Books. 
Stephen, C. and Plowman, L. (2002) ICT in Pre-School: A 'Benign Addition'? Glasgow: Learning and Teaching Scotland.

Stephen, C. and Plowman, L. (2003) 'Come Back in Two Years': A Study of the Use of ICT in Pre-School Settings. Glasgow: Learning and Teaching Scotland.

Turbill, J. (2001) A researcher goes to school: using technology in the Kindergarten literacy curriculum. Journal of Early Childhood Literacy 1 (3), 255-279.

Volk, D. with de Acosta, M. (2004) Mediating networks for literacy learning: the role of Puerto Rican siblings. In Gregory, E., Long, S. and Volk, D. (eds) Many Pathways to Literacy: Young Children Learning with Siblings, Grandparents, Peers and Communities. London: RoutledgeFalmer.

Vygotsky, L. (1978) Mind in Society. Cambridge, Mass: Harvard University Press.

Wegerif, R. (2002) Literature Review in Thinking Skills, Technology and Learning. Bristol: NESTA Futurelab.

Wegerif, R. (2004) The role of ICT as catalyst and support for dialogue. NALDIC Quarterly, 1(4), 4-11.

Wegerif, R. and Dawes, L. (2004) Thinking and Learning with ICT: Raising Achievement in Primary Classrooms. London: Routledge. 